Results In patients with RA the significant increasing of SF immunoglobulins, especially IgG, circulating immune complexes, complement proteins, IL-1 beta and TNF-alpha was found. Creactive protein was relatively low. There was no significant serum IgG, phagocyte activity, IL-1 beta and TNF-alpha elevation. RF at the RA onset was higher in SF, than in serum. In RA seronegative patients was determined exclusively in the SF in low quantity.

Conclusion We concluded that immunological investigation of SF is important tool for RA diagnosis, especially in activity processes estimation.

\section{AB0012 URINE AND PLASMA INTERLEUKIN-6 (IL-6) LEVELS IN PATIENTS WITH GLOMERULAR DISEASE}

D Soldo-Jure?a, D Vergles, MI Ėulo, K Gale?iæ. Department of Medicine, University Hospital Dubrava, Zagreb, Croatia

\subsection{6/annrheumdis-2001.811}

Background IL-6 is involved in the induction of acute phase protein synthesis in liver cells, as well as in other systemic changes associated with infection and tissue injury. IL-6 is probably produced by mesangial cells in patients with mesangial proliferative glomerulonephritis (MPG).

Objectives The aim of this study was to determine IL-6 levels in urine and plasma of patients with primary glomerular disease ? MPG and of patients with systemic lupus erythematosus who had MPG (II class of lupus nephritis according to WHO).

Methods The study included 23 patients and 10 healthy volunteers. 12 out 23 patients had MPG and 6 had SLE and MPG. 5 out 23 patients had membranoproliferative glomerulonephritis. Plasma and urine IL-6 levels were determined using sensitive bioassay.

Results Measurable quantities of IL- 6 were detected in the urine (mean $\pm \mathrm{SEM}=24.75 \pm 0.61 \mathrm{pg} / \mathrm{ml} ; \mathrm{n}=10$ ) as well as in the plasma $(14.18 \pm 0.43 \mathrm{pg} / \mathrm{ml} ; \mathrm{n}=10)$ of healthy controls. Increased urine IL-6 levels were found in patients with primary and secondary (with SLE) MPG $(29.75 \pm 0.75$; $\mathrm{n}=17$; $\mathrm{p}<$ 0.01 ), while in patients with membranoproliferative glomerulonephritis the IL-6 concentration did not differ from the control values $(25.24 \pm 1.4 ; \mathrm{n}=5 ; \mathrm{p}>0.05)$. In plasma the mean IL-6 concentration in patients with MPG and SLE was slightly but not significantly higher than in the healthy subjects.

Conclusion The data show that the presence of IL-6 in urine but not in plasma, may be a valuable indication of the disease in the majority of patients with primary MPG and patients with SLE who had MPG.

\section{AB0013 SOME CYTOKINES AND BONE MARKERS IN OSTEOARTHRITIS}

H Hulejova, P Spacek, M Adam. Connective Tissue Research, Institute of Rheumatology, Prague, Czech Republic

\subsection{6/annrheumdis-2001.812}

Background Osteoarthritis (OA) is a dynamic process involving joint as an organ and causing successive loss of structural integrity of different joint compartment constituents. OA is not a single disease entity but it is a group of overlapping disorders in which articular cartilage and subchondral bone are disturbed. Synovitis and formation of granulation tissue in subchondral bone take place in many patients with OA. Therefore at least some OA forms may be classified rather as inflammatory disease rather than degenerative disease. It is also a process where different biochemical factors besides mechanical take place. ${ }^{1}$

Objectives To elucidate the participation of some cytokines in OA pathological processes and to compare their values with those of bone markers.

Methods In sera of 32 OA patients in early as well as late stages with levels of Il-1b, Il-6, Il-8 and TNFa were established in Immulite (DPL, Los Angeles, CA, USA). Because serum levels of Il-1b and Il-6 were normal in all patients, in extracts from tissues obtained in TEP installation, only IL- 8 and TNFa levels concentration were determined. Urinary pyridinoline (UPD) and deoxypyridinoline (UDPD) were determined with HPLC in the equipment of Spectra Physics (San Jose, CA, USA, type SP). ${ }^{2}$ Chondrex (YKL-40) and bone alkaline phosphatase (BAP) were measured with ELISA test (Metra Biosystems, CA, USA). Values of Il-8 and TNFa don't correlate with Upyr and chondrex levels. Results Concentration of cytokines in sera, synovial fluids and tissue extracts were increased only in some patients and mainly in synovial fluid. Markers of activity were increased in the both sera and tissue extracts.

Conclusion According to the results obtained Il-1b and Il-6 do not play any role in OA processes. On the other hand tissue concentrations of Il- 8 and TNFa do not correlate with bone markers and therefore they not reflex activity of pathological process.

\section{REFERENCES}

1 Westacott $\mathrm{Cl}$, Sharif M. Cytokines in osteoarthritis: mediators or markers of joint destruction? Semin Arthritis Rheum. 1996;25(4): 254-72

2 paèek $P$, Hulejová $H$, Adam M. Ion exchange HPLC determination of pyridinium crosslinks in urine as markers of bone resorption. I Liq Chem Rel Technol. 1997;20(12):1921-30

\section{AB0014 TUMOUR NECROSIS FACTOR-ALPHA IN PATIENTS WITH SYSTEMIC LUPUS ERYTHEMATOSUS}

AG Borodin, AA Baranov, EL Nassonov, NG Klukvina. Department of Therapy, Medical Academy, Yaroslavl, Russia

\subsection{6/annrheumdis-2001.813}

\section{Background}

Objectives

Methods To obtain information about the involvement of tumour necrosis factor-alpha (TNF-a) in the pathophysiology of SLE this cytokine was measured, by an enzyme linked immunosorbent assay, in sera from 109 patients (pts) with systemic lupus erythematosus (SLE) (44 men and 65 women). The results were compared with 20 healthy subjects. The mean level of TNFalpha was $84,4+43,2 \mathrm{pg} / \mathrm{ml}$ in males $(0-859 \mathrm{pg} / \mathrm{ml})$ and 11 $+7,4 \mathrm{pg} / \mathrm{ml}$ in females $(0-192,2 \mathrm{pg} / \mathrm{ml})$. The difference between male and female cohorts was significant $(\mathrm{p}<0,002)$. The mean level of TNF-alpha was $0,6+0,8(0-8,5 \mathrm{pg} / \mathrm{ml})$ in donors. Patients of both groups (males and females) had a significantly higher serum TNF-alpha than control subjects $(\mathrm{p}<0,001)$.

Results TNF-alpha was found positive (more than 3s.d. above the mean in normal controls) in 17 females (26\%), 36 males $(81,8 \%)$ in pts with SLE compared to 1 person $(5 \%)$ of normal controls $(\mathrm{p}<0,05)$. Data differed statistically between patients in male and female groups and controls. The raised level of TNF-alpha was defined as low, moderate and high positive. We have found the low-positive TNF-alpha in 2 pts (3\%), the moderate-positive in 8 pts $(12 \%)$ and the high-positive in 7 pts $(10 \%)$ in females. We found significant positive correlation 